\title{
Analisis Self Defelopment Pasca Pemberian Pelatihan Di Unit Pelaksana Teknis Latihan Kerja (UPT-LK) Wilayah 1 Pekanbaru
}

\author{
${ }^{1}$ Helsa Oktavia. K, ${ }^{2}$ Febri Yuliani \\ ${ }^{12}$ Program Studi Pascasarjana Ilmu Administrasi Publik Universitas Riau \\ e-mail : Helsaoktavia@gmail.com
}

\begin{abstract}
Abstrak
Analisis Self Development Pasca Pemberian Pelatihan Di Unit Pelaksana Teknis Latihan Kerja (UPT-LK) Wilayah 1 Pekanbaru.Penelitian ini bertujuan untuk menganalisis pengembangan diri setelah pemberian latihan di UPT-LK wilayah 1 Pekanbaru serta factor-faktor apa saja yang menghambat pengembangan diri setelah pemberian pelatihan di UPT-LK wilayah 1 Pekanbaru. Jenispenelitian yang digunakan adalah jenis penelitian kualitatif.Informan dalam penelitian ini adalah pegawai bagian pelatihan di UPT-LK Wilayah 1 Pekanbaru,pegawai bagian tata usaha di UPT-LK Wilayah 1 Pekanbaru,instruktur pelatihan di UPT-LK Wilayah 1 Pekanbaru, dan peserta pelatihan yang telah mengikuti pelatihan di UPT-LK Wilayah 1 Pekanbaru.Teknik pengumpulan data dilakukan dengan metode wawancara, observasi, dan dokumentasi.Hasil penelitian diketahui bahwa pengembangan diri yang dilakukan peserta pelatihan setelah menyelesaikan pelatihan di UPT-LK wilayah 1 Pekanbaru masih kurang baik. Factor penghambat pengembangan diri peserta pelatihan setelah mengikuti pelatihan adalah tidak memiliki tujuan yang pasti, suka berfikir negative, kurangnya motivasi, malu atau takut untuk memulai sesuatu dan terjadinya Pandemi Covid-19 (corona virus).
\end{abstract}

Kata kunci:pengembangan diri, pelatihan, potensi, berfikir positif, kreativitas, kemampuan, ketekunan

\begin{abstract}
Self Development Analysis After Providing Training At The Technical Implementation Unit for Job Training (UPT-LK) Region 1 Pekanbaru. This study aims to analyze self-development after giving training at UPTLK region 1 Pekanbaru and what factors hinder self-development after providing training at UPT-LK region 1 Pekanbaru. This type of research is a type of qualitative research. The informants in this study were employees of the training section at UPT-LK Region 1 Pekanbaru, administrative staff at UPT-LK Region 1 Pekanbaru, training instructors at UPT-LK Wilayah 1 Pekanbaru, and training participants who had attended training at Regional UPT-LK. 1 Pekanbaru. The data collection technique is done by using interview, observation, and documentation methods. The results showed that the self-development carried out by the training participants after completing the training at UPT-LK region 1 Pekanbaru was still not good enough. Factors inhibiting the self-development of trainees after attending the training are not having a definite goal, like to think negatively, lack of motivation, shame or fear of starting something and the occurrence of the Covid-19 Pandemic (corona virus).
\end{abstract}

Keywords: self-development, training, potential, positive thinking, creativity, ability, persistence

\section{PENDAHULUAN}

Provinsi Riau merupakan salah satu provinsi terkaya di Indonesia, dan sumber dayanya didominasi oleh sumber alam, terutama minyak bumi, gas alam, karet, kelapa sawit dan perkebunan serat. Sehingga provinsi Riau dikenal sebagai salah satu kota penghasil minyak di Indoesia. Dengan sumber daya alam yang berlimpah tentu harus didukung dengan pengelolaan yang baik oleh sumber daya manusianya. Untuk mendukung hal tersebut kualitas sumber daya manusia harus diperhatikan, agar dapat mendukung perkembangan pada sektor lainnya. Itulah mengapa perkembangan sumber daya manusia sering kali dikatakan sebagai kunci dari perkembangan teknologi, perkembangan bisnis, perkembangan budaya dan perkembangan lainnya. 
Meningkatan kualitas sumber daya manusia tidak hanya dilakukan untuk diri sumber daya manusia tersebut agar menjadi lebih baik, tetapi meningkatkan kualitas sumber daya manusia juga akan mempengaruhi peningkatan daerah, apakah dari segi ekonomi, politik, social, budaya dan lainnya. Pemerintah daerah dikatakan berhasil apabila mampu meningkatkan kesejahteraan masyarakat daerahnya termasuk peningkatan kualitas sumber daya manusia daerahnya. Banyak hal yang akan mempengaruhi dengan meningkatnya kualitas sumber daya manusia, salah satunya adalah mampu meningkatnya taraf hidup masyarakat daerah.

Dalam membantu perkembangan tersebut pemerintah memiliki peran untuk membantu perkembangan sumber daya manusia melalui berbagai macam program agar sumber daya manusia daerahnya terus berkembang dan memiliki kualitas, keterampilan dan kemampuan yang diinginkan perusahaan atau organisasi. Walaupun setiap tahun sumber daya manusia yang mencari pekerjaan terus meningkat tanpa di imbangi dengan adanya lapangan pekerjaan dan membuat masih banyak sumber daya manusia yang tidak memiliki pekerjaan. Namun pemerintah tetap harus memastikan masyarakatnya dapat terus berkembang, memiliki keterampilan dan kemampuan.Pencari kerja meliputi hampir semua kalangan mulai dengan lulusan sekolah dasar sampai lulusan sarjana masih banyak yang belum memiliki kesempatan kerja seperti yang diharapkannya. Pada pada Februari 2019, berdasarkan hasil berita resmi statistik publikasi Keadaan Ketenagakerjaan Provinsi Riau Februari 2019 jumlah Angkatan Kerja Provinsi Riau sebanyak 3,30 juta orang, bertambah 0,5 ribu orang dibanding Februari 2018 (setahun yang lalu). Komponen pembentuk Angkatan Kerja adalah penduduk yang bekerja dan pengangguran. Sementara itu, jumlah pengangguran sebanyak 183,70 ribu orang, mengalami penurunan sebanyak 4,71 ribu orang dibanding setahun yang lalu.

\section{Gambar 1.1}

\section{Tingkat Pengangguran Terbuka (TPT) Provinsi Riau Menurut Tingkat Pendidikan Tertinggi yang Ditamatkan (persen), Februari 2017- Februari 2019}

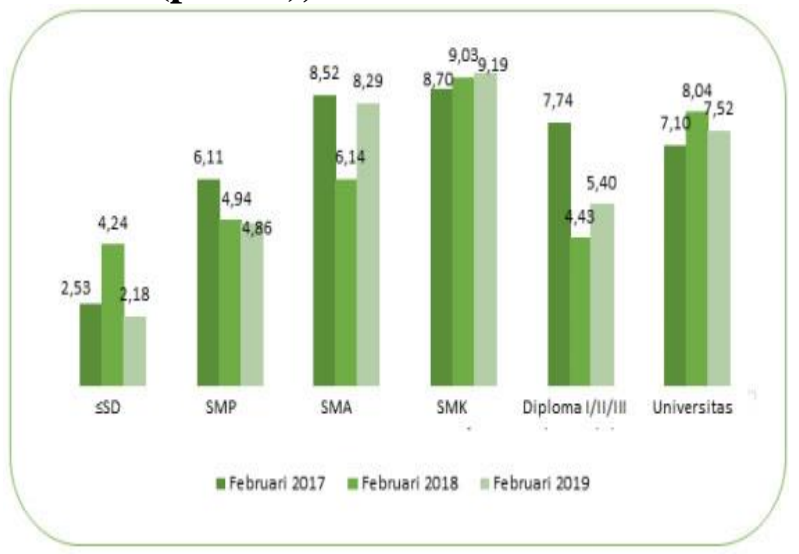

Sumber: BPS.go.id, 2019.

Apabila diliat dari upaya pemerintah, pihak Pemerintah Kota telah berupaya untuk dapat menciptakan berbagai lapangan pekerjaan. Salah satunya ialah dengan mengundang para investor untuk menanamkan modal dan membuka usaha di Kota Pekanbaru.Selain itu, dikatakan bahwa Pemerintah kota juga menggelar berbagai kegiatan berupa pelatihan usaha untuk para pelaku usaha kecil menengah. Kegiatan tersebut juga ditujukan untuk para anak muda yang diharapkan dapat menciptakan lapangan pekerjaan baru sehingga nantinya akan dapat menyerap dan mengurangi tingginya angka pengangguran.

Selain itu salah satu cara yang dilakukan oleh pemerintah dalam menanggulangi pengangguran adalah dengan memberikan pelatihan kerja sebagai bekal untuk dipergunakan dalam meningkatkan skill dan kemampuan sumber daya manusia di dalam persaingan tenaga kerja yang semakin banyak melalui Unit Pelaksana Teknis Latihan Kerja (UPT-LK) Wilayah I Pekanbaru. Pelatihan didefinisikan sebagai 
suatu proses pembelajaran secara sistematis yang mencakup penguasaan pengetahuan, meningkatkan keterampilan, serta perubahan sikap dan perilaku guna meningkatkan kinerja karyawan (Suparyadi, 2015:183). Dengan demikian, pelatihan mengandung tiga aspek penting yang perlu diwujudkan dalam pelaksanaannya, yaitu penguasaan pengetahuan, meningkatnya keterampilan, serta terjadinya perubahaan sikap dan perilaku. Menurut Simamora (2004:274) pelatihan merupakan proses yang mencoba untuk menyediakan bagi seorang karyawan informasi, keahlian dan pemahaman atas organisasi dan tujuan. Pelatihan dirancang untuk meningkatkan keahlian, pengetahuan, pengalaman, atau perubahan sikap seseorang.

Pemerintah Provinsi Riau melalui Dinas Tenaga Kerja dan Transmigasi terus berupaya untuk menciptakan sumber daya manusia (SDM) yang terampil dan kreatif. Salah satu upaya yang dilakukan itu dengan memberi pelatihan dan pembekalan ilmu pengetahuan kepada masyarakat, khususnya bagi masyarakat yang belum bekerja. Untuk itu, melalui Program Pemerintah Pusat dan Daerah, Unit Pelaksana Teknis Latihan Kerja (UPT-LK) Wilayah I Pekanbaru, Jalan Terubuk Pekanbaru setiap tahunnya menggelar pelatihan kerja bagi masyarakat umum yang belum bekerja diberikan keterampilan atau keahlian.

Tujuan program pelaksanaan pelatihan keterampilan adalah untuk menjawab tantangan yang hadapi bagaimana menciptakan, membina dan memberdayakan tenaga kerja yang begitu banyak untuk menangani pertumbuhan industri di Riau yang sangat cepat. Maka Unit Pelaksana Teknis Latihan Kerja merupakan salah satu lembaga pendidikan dan pelatihan untuk mempersiapkan hal tersebut. Pendidikan dan pelatihan yang diberikan terdiri dari berbagai pelatihan keterampilan yang dibutuhkan oleh masyarakat.Dalam pemberian pelatihan kepada para sumber daya manusia, hasil akhir yang ingin dicapai adalah bagaimana pelatihan yang diberikan dapat membawa kepada kehidupan yang lebih baik, apakah itu dengan mendapatkan pekerjaan atau kah mengelola pelatihan yang berikan untuk dikembangan bagi diri sendiri sehingga akhirnya dapat membuka lapangan pekerjaan.

Pelatihan yang diberikan pemerintah tentu membawa harapan bahwa pelatihan tersebut akan membawa hasil (outcome) yang baik sesua dengan tujuan dari pelaksanaan pelatihan tersebut baik bagi individu, organisasi dan lingkungan sekitar. Banyak harapan muncul di dalam pemberian pelatihan bagi masyarakat agar dapat mengembangkandirinya sesuai dengan hasil akhir yang diharapkan. Karena harapan-harapan tersebut timbulah pertanyaan bagaimana pengembangan diri masyarakat yang mengikuti pelatihan setelah mengikuti proses pelatihan, apakah sesuai dengan yang diharapkan, ataukah sebaliknya.

\section{METODE}

Jenis penelitian ini adalah jenis penelitian kualitatif, penelitian kualitatif dipilih dengan alasan untuk menganalisa dan mendapatkan pemahaman yang luas dan mendalam tentang fenomena yang terjadi terkait self developmentpeserta pasca pemberian pelatihan di UPT-LK wilayah 1 Pekanbaru. Adapun lokasi pada penelitian ini adalah di Unit Pelaksana Teknis Latihan Kerja (UPT-LK) Wilayah 1 Pekanbaru. Dalam penelitian ini peneliti menggunakan teknik Puposive sampling di mana peneliti memilih informan yang peneliti anggap mengetahui tentang fenomena yang diteliti.Adapun informan didalam penelitian ini adalah: (1) Pegawai bagian pelatihan di UPT-LK Wilayah 1 Pekanbaru, (2) Pegawai bagian tata usaha di UPT-LK Wilayah 1 Pekanbaru, (3) Instruktur pelatihan di UPT-LK Wilayah 1 Pekanbaru, (4) Peserta pelatihan yang telah mengikuti pelatihan di UPT-LK Wilayah 1 Pekanbaru. Teknik yang dilakukan dalam pengumpulan data yaitu melalui wawancara, observasi, dan dokumentasi.

Hambatan yang penulis temui selama proses pelaksanaan penelitian adalah terbatasnya ruang lingkup gerak selama masa pandemic covid-19 (corona virus). 


\section{HASIL DAN PEMBAHASAN}

Unit Pelaksana Teknis (UPT-LK) wilayah 1 Pekanbaru memiliki wewenang untuk mengadakan pelatihan yang bertujuan untuk memberikan pengetahuan dan keterampilan dasar kepada masyarakat di daerah perkotaan dan perdesaan. Pelatihan yang di berikan memang lebih di tekankan kepada pemberian keterampilan (skill), dapat di katakan bahwa pelatihan pada Unit Pelaksana Teknis (UPT-LK) wilayah 1 Pekanbaru terdiri dari $80 \%$ praktek dan $20 \%$ teori. Hal ini sesuai dengan yang diungkapkan oleh bapak Arfi Yunanda selaku pegawai UPT-LK wilayah 1 Pekanbaru, sebagai berikut:

"Bisa dibilang di upt-lk ni kita lebih banyak praktek dari pada teori. Pokoknya langsung aja. Apa schedule hari ini, contoh langsung praktek. Jadi $80 \%$ itu praktek $20 \%$ teori. Kalau di perkuliahan kan full teori tu, nah kita prakteknya. Kalau dilihat didunia kerja ini butuh apa teori atau skill nya. Nah kebanyakan pelamar itu kurang di skill. Kalau teori bolehlah. Makanya dipelatihan itu memang bisa dibilang full praktek." (Wawancara: Maret 2020)

Dari hasil wawancara diatas dapat dilihat bahwa pemberian pelatihan yang dilakukan di UPT-LK Wilayah 1 Pekanbaru menekankan terhadap keterampilan (skill) maka diharapkan peserta pelatihan memiliki dasar untuk mengambangkan dirinya hingga dapat bersaing didunia kerja saat ini dan meningkatkan taraf hidupnya.

\section{Mengoptimalkan Potensi Diri}

Potensi dapat dikatakan sebagai kemampuan dalam diri seseorang yang belum teraktualisasi, belum dipraktikkan, dan belum digunakan. Potensi ada di dalam diri seseorang tetapi tidak semua orang dapat mengembangkan dan mengoptimalkan potensi yang dimiliki. Berbagai alasan timbul dibalik tidak di optimalkannya potensi tersebut.

Berdasarkan hasil wawancara dan observasi ditarik kesimpulkan bahwa informan masih bingung dengan potensi yang ada didalam dirinya, sehingga didalam mengoptimalkan potensi yang ada dapat dikatakan kurang dioptimalkan. Ketidak pekaan terhadap potensi yang dimiliki menjadi salah satu penghambat dalam melakukan pengembangan diri. Pengembangan diri yang baik adalah bagaimana seseorang mengenali diri sendiri, termasuk potensi yang dimilikinya. Namun ada kalanya seseorang mengetahui potensi dirinya dan memang sengaja tidak atau belum mengembangkannya secara maksimal karena beberapa alasan. Hal ini tentu menjadi pilihan masing-masing individu untuk memilih yang mereka inginkan.

Pengoptimalkan potensi dilakukan oleh salah satu informan yaitu Chairunnisa selaku peserta pelatihan di UPT-LK Wilayah 1 Pekanbaru, sebagai berikut:

"Ketika SMA kan ada bikin kerajinan, nah saya dapat bagian menjahit jadi saya bikin alas meja dari bahan-bahan sisa kak. Tapi dulu jahit pake tangan gitu, dibilang guru saya jahitannya rapi. Tapi saya gak ada background menjahit. Karena dibilang rapi bagus, pas ada pelatihan saya pengen ikut pelatihan menjahit. Saya tau saya bisa, tapi ya harus belajar. Kalau pendidikan terakhir saya S1 pendidikan." (Wawancara Maret 2020)

Potensi yang ada pada diri seseorang mungkin tidak langsung disadari oleh individu. Terlihat dari pernyataan di atas bahwa yang menyadari potensi menjahit informan adalah gurunya ketika duduk dibangku SMA, yang kemudian memberikannya motivasi untuk mengoptimalkan potensi yang ada. Setalah menyadari potensi yang dimiliki sesorang harus memiliki motivasi untuk megembangkannya salah satunya adalah dengan mengikuti pelatihan.Dengan mengikuti pelatihan menunjukkan bahwa informan telah berusaha mengembangkan potensi yang dimiliki melalui pelatihan yang diadakan oleh UPT-LK Wilayah 1 Pekanbaru.

Berdasarkan hasil wawancaradanobservasidapat ditarik kesimpulan bahwa masih kurangnya pengoptimalan potensi yang dilakukan oleh peserta pelatihan di UPT-LK Wilayah 1 Pekanbaru. Hal ini dikarenakan beberapa dari informan masih bingung dan kurang mengenali potensi yang dimiliki dan 
sebagian lain belum mengoptimalkan potensi yang ada pada dirinya sendiri.Terkadangseseorang memerlukan orang lain untuk membantunya, sesuai dengan ciri bahwa manusia adalah mahkluk social. Untuk itu penting bagi tiap individu untuk terus bersosialisasi dan berkomunikasi tentang apa yang mungkin tidak disadari oleh dirinya sendiri.

\section{Berfikir Positif}

Berpikir positif adalah kemampuan berpikir seseorang untuk menilai pengalaman-pengalaman dalam hidupnya, sebagai bahan yang berharga untuk pengalaman selanjutnya dan menganggap semua itu sebagai proses hidup yang harus diterima. Semua yang kita lakukan asal mulanya datang dari pikiran kita, ketika pikiran dipenuhi dengan pikiran-pikiran negative hal tersebut akan terbawa ke alam bawah sadar dan ikut memperngaruhi sikap, sifat dan tidakan seseorang. Sehingga secara tidak langsung pikiran akan mempengaruhi hasil yang akan didapatkan.

Berfikir positif dipandang sebagai bagian keyakinan terhadap diri sendiri tentang apa yang dilakukan saat ini maupun yang akan dilakukan dimasa depan.Seseorang yang selalu berfikir positif dapat terlihat jelas dengan keyakinan terhadap diri nya dan semangat yang diperlihatkannya di dalam mengerjakan sesuatu. Oleh karena itu berfikir positif dikatakan sebagai dasar dari motivasi. Motivasi yang timbul dari dalam diri sendiri dan didukung dengan motivasi dari luar diri akan menjadi motivasi yang akan terus hidup dan memberikan semangat terhadap seseorang didalam hidupnya.

Berdasarkan wawancara dengan informan dapat ditarik kesimpulan bahwa kemampuan untuk mengontrol pikirannya dengan selalu berfikir positif sebagai salah satu dasar pengembangan diri dari para peserta pelatihan UPT-LK wilayah 1 Pekanbaru sudah cukup baik. Hal ini dikarenakan 3 dari 6 peserta pelatihan memilih untuk berfikiran positif didalam kehidupannya, dan hal ini menunjang pengembangan dirinya. Dimana 2 dari 3 orang tersebut telah melakukan pengembangan diri dengan bekerja dan memulai usaha mandiri. Sedangkan 3 orang perserta pelatihan yang mengatakan berfikiran negative terlebih dahulu karena beberapa alasannya, 2 diantaranya masih belum melakukan pengembangan diri yang diharapkan.

\section{Menumbuhkan Kreativitas}

Kreativitas merupakan sesuatu yang penting untuk setiap orang di dalam pengembangan dirinya. Pengembangan diri menuntut seseorang untuk terus berfikir bagaimana untuk berkembang dan berubah menjadi lebih baik dari sebelumnya. Selalu berfikir bagaimana menciptakan (to create) sesuatu dan terus berinovasi (to innovate) di dalam berubahan yang selalu terjadi dilingkungan sekitar. Perubahan mengharuskan kita untuk ikut berubah, beradaptasi, bergandengan bahkan untuk lebih maju dari perubahan itu sendiri. Sehingga kreatifitas dibutuhkan untuk dapat mengelola atau untuk terus mampu mengikuti perubahan yang ada.

Bagi peserta pelatihan kreativitas diperlukan untuk terus berfikir dalam memecahkan masalahnya, terutama di dalam menemukan pekerjaan, membuka usaha mandiri ataupun untuk meningkatkan pengetahuan yang telah didapatkan selama mengikuti pelatihan dan mengembangkannya.Karena kreativitas salah satu factor penting didalam terciptanya keunggulan dan daya saing sehingga terus dapat berkembang dan berubah menjadi lebih baik.

Berdasarkan wawancara dengan informan diketahui bahwa informan menginformasikan jika mereka bukanlah orang yang memiliki kreativitas yang tinggi. Dan berdasarkan hal tersebut dapat ditarik kesimpulan bahwa kreativitas dari para peserta pelatihan UPT-LK wilayah 1 Pekanbaru masih kurang baik. Hal ini disimpulakan dari pernyataan peserta pelatihan yang mengatakan bahwa mereka bukanlah orang-orang yang kreatif.

Bagaimana seorang individu dapat menumbuhkan kreativitas jika individu tersebut tidak yakin dan mengatakan bukanlah orang yang memiliki kreativitas. Didapatkan alasan bahwa individu terbiasa dengan aturan yang terikat dan menolak untuk melakukan hal-hal kreatif bagi perkembangan dirinya 
sendiri.Padahal kreativitas tidak selalu hal-hal yang besar dan baru, bisa saja hal-hal kecil yang mampu mereka lakukan dan kembangkan. Baik dilingkungan rumah, social dan lingkungan kerja. Karena kreativitas tida terbatas didalam suatu lingkungan saja.

\section{Mengembangkan Kemampuan Diri}

Kemampuan diri adalah sesuatu yang didapatkan dari hasil proses pembelajaran, baik itu proses pembelajaran formal maupun pembelajaran informal yang dilakukan secara terus-menerus. Oleh karena itu kemampuan bukanlah sesuatu yang didapatkan secara alami, yang sudah ada atau di miliki dari lahir. Sehingga kemampuan dikatakan berbeda dengan potensi. Seorang individu dapat memilih kemampuan apa yang ingin ia miliki. Dengan memiliki kemampuan maka akan membuat perbedaan dari cara bersikap, merasakan dan berfikir. Semakin tinggi tingkat kemampuan seseorang semakin berbeda pula bagaimana cara ia bersikap berpikir dan mengatasi sesuatu. Mengembangkan kemampuan diri tidak hanya terbatas terhadap diri sendiri tersebut, Namun juga memerlukan Interaksi terhadap orang orang lain, lingkungan dan teknologi. Interaksi terhadap dengan orang lain akan membantu kita mengembangkan diri menjadi lebih baik atau lebih cepat dari yang diharapkan karena secara tidak langsung kita belajar dari pengalaman orang tersebut. Hal ini sesuai dengan yang telah dijelaskan sebelumnya bahwa kemampuan yang dimiliki setiap individu dapat menghasilkan perbedaan, karena hal tersebut seseorang perlu untuk terus berinteraksi dengan orang lain sehingga mengadaptasi berbagai perbedaan-perbedaan yang ada dan membuatnya menjadi kekuatan di dalam pengembangan kemampuan dirinya.

Mengembangkan kemampuan diri tidak terlepas dari faktor lingkungan sekitar. Lingkungan adalah keseluruhan atau setiap aspek dan gejala fisik dan sosial kultural yang mempengaruhi individu. Untuk melakukan pengembangan diri yang baik seseorang harus mampu untuk memahami dan melihat lingkungan sekitarnya. Apakah lingkungan tersebut dapat mendukung pengembangan dirinya, apabila lingkungan tidak mendukung maka akan sulit bagi seseorang untuk dapat mengembangkan dirinya, Oleh karena itu lingkungan perlu dipertimbangkan secara lebih mendalam.

Hal lain yang perlu diperhatikan dalam mengembangkan kemampuan diri adalah Teknologi. Hal ini pasti sudah disadari oleh banyak orang bahwa teknologi memerankan peranan penting didalam dunia kerja sampai kepada kehidupan kita sehari-hari. Oleh karena itu teknologi tidak dapat kita lepaskan begitu saja untuk membantu kita dalam melakukan pengembangan kemampuan diri. Dapat dikatakan bahwa semakin berkembangnya teknologi maka semakin kita harus mau mengejar dan di sesuai perkembangan yang ada.

Berdasarkan wawancara dengan informan peneliti dapat menyimpulkan bahwa pengembangan kemampuan diri dari para peserta pelatihan setelah menyelesaikan pelatihan di UPT-LK wilayah 1 Pekanbaru belum cukup baik. Hal ini dikarenakan setelah mengikuti pelatihan dan menyelesaikan pelatihan peserta pelatihan masih kurang didalam melakukan pengembangan kemampuan lagi.

\section{Ketekunan}

Di dalam melakukan pengembangan diri memang memiliki banyak aspek seperti poin-poin yang telah disampaikan diatas untuk dapat dikembangkan dengan baik, namun dari semua itu ketekunan menjadi syarat utama di dalam melakukan pengembangan diri. Tidak jarang orang yang memiliki intelektual yang tinggi dan kemampuan yang tinggi gagal dalam mencapai tujuannya. Hal ini dikarenakan kurangnya ketekunan dalam menjalani atau mengerjakan sesuatu. Sebaliknya orang yang memiliki tingkat ketekunan yang tinggi lebih banyak berhasil dalam mencapai tujuannya, karena tidak mudah menyerah dan terus melakukan sesuatu sampai ia mencapai keberhasilan. Hal ini dibuktikan dengan banyaknya penemuan yang sangat berguna bagi kehidupan kita saat ini dimulai dari ketekunan para ahli atau penemu alat atau teori-teori yang sangat membantu kehidupan kita sekarang ini. 
Ketekunan hadir apabila yang dilakukan dengan sepenuh hati atau datang dari hati. Orang-orang yang tekun selalu berusaha untuk mencapai yang terbaik dari apa yang ia usahakan dan tidak mudah menyerah untuk mencapai tujuannya. Dari hasil wawancara dan observasi dapat dilihat bahwa mereka adalah orang-orang yang tekun. Untuk beberapa informan hal ini benar adanya karena dibuktikan dengan terus melakukan usaha sampai mencapai tujuannya apakah itu bekerja atau memulai usaha. Dan sebagian lain telah melakukan nya dengan fokus yang berbeda sesuai dengan tujuannya saat ini.

Hal ini juga didukung oleh pernyataan instruktur dan pegawai di UPL-TK wilayah 1 Pekanbaru yang mengatakan bahwa para peserta selama masa periode pelatihan dinilai sebagai orang-orang yang memiliki ketekunan yang tinggi. Instruktur menilai bahwa selama proses pemberian latihan para peserta mengikuti pelatihan dengan semangat belajar yang tinggi.Pernyataan tersebut juga didukung oleh bapak Arfi Yunanda selaku pegawai di UPT-LK Wilayah 1 Pekanbaru, sebagai berikut:

"Dari yang saya perhatikan selama periode pelatihan itu terlihat semua semangat, tekun, rajin ya. Soalnya dimula dari proses penerimaan pun kita memang mengutamakan orang-orang yang memerlukan, yang bersemangat, memiliki kemauan yang kuat untuk mengikuti pelatihan. Jadi selama periode pelatihan hampir semuanya itu melakukan yang terbaik. Tidak mudah untuk bisa lulus pelatihan, kamu liat sajalah yang daftar ratusan orang, yang bisa kita terima Cuma 16 orang per jurusan. Berapa banyak itu yang gak lolos. Jadi harus dijaga sekali ketika diterima menjadi siswa pelatihan. Harus belajar sunggung-sungguh." (Wawancara Maret 2020)

Dari hasil wawancara bersama instruktur dan pegawai UPT-LK wilayah 1 Pekanbaru didapatkan kesimpulan bahwa dimulai dari proses seleksi atau proses penerimaan calon peserta pelatihan salah satu kriteria penerimaan adalah calon peserta yang memiliki semangat yang tinggi, tekun, dan yang memang berkeinginan atau membutuhkan pengembangan keterampilan bagi dirinya. Dan berdasarkan hasil observasi dan wawancara bersama peserta pelatihan didapati pula kesimpulan bahwa setelah menyelesaikan proses pelatihan, peserta pelatihan masih mencari dan melamar pekerjaan, namun salah satu penghalang didalam proses pencarian kerja peserta pelatihan sudah dihadapi dengan berbagai halangan sesuai dengan kondisi masing-masing. Seperti sudah ada yang menikah, membantu orang tua dirumah, dan yang paling menjadi penghalang adalah dengan adanya pandemic covid-19 yang dimulai sejak awal tahun 2020.

Seperti yang diketahui bahwa banyak sekali perusahaan yang tidak sanggup untuk bertahan di dalam kondisi situasi pandemi saat ini, mengingat mulai dari sekolah, kantor pemerintahan, perusahaan, Mall, hingga usaha-usaha kecil lainnya harus ditutup untuk mencegah penularan pandemic di Indonesia. Kerugian akibat ditutupnya perusahaan hingga usaha kecil membuat sumber pendapatan dari perusahaan tersebut menjadi menurun drastis dan sangat tidak stabil, sehingga harus melakukan pemulangan karyawan atau melakukan penyusutan karyawan. Hal ini Membuat lapangan pekerjaan turut berkurang secara drastis.

Berdasarkan hasil wawancara dengan informan dapat ditarik kesimpulan bahwa ketekunan dari para peserta pelatihan setelah menyelesaikan pelatihan di UPT-LK wilayah 1 Pekanbaru sudah baik, salah satu yang menjadi penilaian ialah ketekunan didalam mencari pekerjaan ataupun membuka usaha mandiri sesuai dengan tujuan pengembangan dari pelatihan di UPT-LK wilayah 1 Pekanbaru. Para peserta pelatihan tetap mencari informasi pekerjaan walaupun terhambat oleh lingkungan dimana pandemic sedang terjadi dimana-mana dan mengakibatkan banyaknya hal-hal yang diluar kendali baik dari segi ekonomi, social, budaya dan politik. Seperti contoh dalam bidang ekonomi dimana perekonomian masyarakat Indonesia sedang menurun, salah satu alasan hal tersebut terjadi dikarenakan dibatasinya ruang gerak masyarakat atau yang lebih dikenal dengan PSBB (Pembatasan Sosial Berskala Besar) hingga mempengaruhi distribusi pelaku usaha kecil, menengah hingga besar. Dan karena hal tersebut perusahaan mengalai kerugian dan sampai pada keputusan untuk melakukan PHK (Pemutusan Hubungan Kerja) atau pemulangan karyawan sementara yang terjadi secara bersamaan. Dari sini dapat dilihat bahwa 
dengan pengurangan karyawan yang dilakukan oleh perusahaan membuat para pencari kerja memiliki kesempatan yang jauh lebih kecil dari sebelumnya. Walaupun begitu para informan tetap berusaha mencari informasi lowongan pekerjaan dan tetap mencoba untuk terus melamar pekerjaan ditengah situasi yang semakin sulit tidak hanya bagi mereka namun bagi setiap orang yang terkena dampak dari pandemic ini.

\section{Faktor-Faktor Penghambat Pengembangan Diri Peserta Pelatihan Pasca Pemberian Latihan di Unit Pelaksana Teknis Latihan Kerja (UPT-LK) Wilayah 1 Pekanbaru}

Dalam melakukan pengembangan diri Para individu tentu Mengalami banyak hambatan dalam prosesnya, apakah hambatan tersebut dating dari diri sendiri maupun dari orang Orang lain dan lingkungan sekitar. Untuk mengetahui apa saja hambatan-hambatan dalam pengembangan diri peneliti telah melakukan wawancara dan observasi terhadap para informan dan orang-orang terkait di dalam pelaksanaan pelatihan di UPT-LK wilayah 1 Pekanbaru. Maka peneliti akan menguraikan temuan-temuan dan hambatan-hambatan dalam pengembangan diri yang penulis dapatkan antara lain : (1) Tidak mempunyai tujuan yang pasti, (2) Berfikiran negatif, (3) Kurangnya motivasi, (4) Malu atau takut untuk memulai sesuatu, dan (5) Terjadinya Pandemi Covid-19 (corona virus).

\section{KESIMPULAN}

Berdasarkan hasil analisa dan observasi serta pembahasan pada bab-bab sebelumnya maka dalam bab ini peneliti akan membuat suatu kesimpulan serta memberikan saran-saran yang diharapkan bisa mampu mendatangkan manfaat bagi Unit pelaksana teknis latihan kerja (UPT-LK) wilayah 1kota Pekanbaru dan masyarakat. Adapun kesimpulan dari hasil penelitian ini yang dapat peneliti sajikan antara lain sebagai berikut :

1. Selama mengikuti proses pelatihan, peserta pelatihan memiliki semangat yang bagus untuk terus mengembangkan dirinya melalui pelatihan untuk meningkatkan kemampuannya (skill). Namun setelah selesai mengikuti proses pelatihan di UPT-LK wilayah 1 Pekanbaru para peserta pelatihan tidak melakukan pengembangan diri secara maksimal.Sehingga dapat dikatakan bahwa pengembangan diri yang dilakukan masih kurang baik. Dilihat dari pengembangan yang diharapkan oleh UPT-LK wilayah 1 Pekanbaru yaitu bekerja atau memiliki usaha, maka hanya 2 dari 6 informan yang mencapai pengembangan diri yang diharapkan. Selanjutnya dilihat dari tahap-tahap pengembangan diri, juga didapatkan kesimpulan bahwa peserta pelatihan tidak dapat melakukan pengembangan diri dengan baik.

2. Faktor-faktor penghambat para peserta untuk melaukan pengembangan diri adalah tidak memiliki tujuan yang pasti, suka berfikir negative, kurangnya motivasi, malu atau takut untuk memulai sesuatu dan terjadinya Pandemi Covid-19 (corona virus).

\section{DAFTAR PUSTAKA}

[1] Bangun, Wilson. 2012. Manajemen Sumber Daya Manusia. Jakarta: Erlangga

[2] Bungin, Burhan. 2011. Penelitian Kualitatif Edisi Kedua. Jakarta: Kencana.

[3] Frinces, Heflin, 2004. Kewirausahaan dan Inovasi Bisnis. Cetakan Pertama, Penerbit: Darusalam, Yogyakarta. 
[4] Gomes, Faustino Cardoso. 2003. Manajemen Sumber Daya Manusia Edisi II. Yogyakarta: Penerbit ANDI.

[5] Hasibuan, Malayu S.P. 2003. Manajemen Sumber Daya Manusia Edisi Revisi. Jakarta: Bumi Aksara.

[6] Hasibuan, Malayu S.P. 2002. Manajemen Sumber Daya Manusia . Bumi Aksara. Jakarta.

[7] Kadarisman. 2012. Manajemen Pengembangan Sumber Daya Manusia. Jakarta: Raja Grafindo Persada.

[8] Maleong, Lexy. 2002. Metodelogi Penelitian Kualitatif. Bandung: Remaja Rosdakarya.

[9] Miles, B. Mathew dan Michael Huberman. 1992. Analisis data Kualitatif. (diterjemahkan Ole: Tjetjep Rohedi Rosidi). Jakarta: Universitas Indonesia.

[10] Mondy, R. Wayne. 2008. Manajemen Sumber Daya Manusia. Jakarta: Erlangga.

[11] Satori, Djam'ah dan Aan Komariah. 2014. Metodelogi Penelitian Kualitatif. Bandung: Alfabeta.

[12] Singarimbun, Masri dan Sofian Effendi. 2006. Metode Penelitian Survei (Editor). Jakarta: LP3ES.

[13] Simamora, Henry. 2004. ManajemenSumberDayaManusia. Yogyakarta: STIE YKPN.

[14] Sugiyono. 2003. Metode Penelitian Administrasi. Bandung: Alfabeta.

[15] Sugiyono. 2011. Metode Penelitian Administrasi Dilengkapi dengan Metode R\&D. Bandung: Alfabeta.

[16] Sugiyono. 2013. Metode Penelitian Kuantitatif, Kualitatif, dan R\&D. Bandung: Alfabeta.

[17] Suparyadi. 2015. Manajemen Sumber Daya Manusia Menciptakan Keunggulan Bersaing Berbasis Kompetensi SDM. Yogyakarta: Andi.

[18] Suwatno dan Donni. 2011. Manajemen SDM Dalam Organisasi Publik dan Bisnis. Bandung: Alfabeta.

[19] Syafri, Wirman dan Alwi. 2014. Manajemen Sumber Daya Manusia dalam Organisasi Publik. Sumedang: IPDN Press.

[20] Tarmudji, Tarsis. 1998. Pengembangan Diri.Yogyakarta: Liberty Yogyakarta.

[21] Triwidodo, Titiek dan Djoko Kristanto. (2004). Pengembangan Kepribadian Sekretaris. Jakarta : Grasindo

[22] Peraturan Pemerintah No. 19 Tahun 1987 Tentang Peraturan Pemerintah (PP) tentang Perubahan Batas Wilayah Kotamadya Daerah Tingkat II Pekanbaru Dan Kabupaten Daerah Tingkat II Kampar 
[23] Peraturan Gubernur Riau Nomor 51 Tahun 2009 Tentang Uraian Tugas Unit Pelaksana Teknis Dinas Tenaga Kerja, Transmigrasi Dan Kependudukan Provinsi Riau

[24] Marmawi. 2009. Persamaan Gender dalam Pengembangan Diri. Jurnal Visi Pendidikan.

[25] Abd. Chayyi Fanani. 2003. Studi tentang Metode Belajar Mahasiswa Pendidikan Agama Islam dalam Upaya Pengembangan Diri di Fakultas Tarbiyah IAIN Sunan Ampel Surabaya Periode 20002002. Skripsi. UIN Sunan Ampel Surabaya.

[26] Bahrudi Efendi Damanik. 2018. Pengaruh Motivasi dan Pengembangan Diri Terhadap Prestasi Kerja Dosen. Jurnal BK \& BI. Politeknik Bisnis Indonesia.

[27] M. P. Mcenrue.1898. Self-Development as a Career Management Strategy. Jurnal of vocational behavior. California State University, Los Angeles.

[28] www.BPS.go.id 